\title{
Aplikasi Edutainment Pendukung Pembelajaran Jarak Jauh TK Merujuk Standar Nasional PAUD
}

\author{
Elviawaty Muisa Zamzami ${ }^{1 \times}$ \\ Ilmu Komputer, Universitas Sumatera Utara \\ DOI: $\underline{10.31004 / \text { obsesi.v5i2.750 }}$
}

\begin{abstract}
Abstrak
Pandemi COVID-19 memicu perubahan pembelajaran Nasional, memunculkan "Belajar Dari Rumah". Penyelenggaraan Pendidikan menjadi Pembelajaran Jarak Jauh (PJJ), tidak terkecuali untuk jenjang Taman Kanak-kanak (TK). PJJ membutuhkan teknologi informasi dan komunikasi termasuk aplikasi edutainment. Aplikasi edutainment dapat mendukung pembelajaran pada jenjang TK. Paper ini memuat penelitian untuk memperoleh aplikasiaplikasi edutainment yang dapat mendukung PJJ TK merujuk Standar Nasional PAUD (SN PAUD). Penelitian kualitatif ini menggunakan teknik observasi terhadap aplikasi-aplikasi pada Google Play Store dengan platform Android. Selanjutnya, melakukan analisis eksperimen terhadap konten dari aplikasi edutainment yang telah dikumpulkan. Bagian akhir paper ini memberikan daftar aplikasi edutainment yang penggunaannya mendukung PJJ jenjang TK, bukan untuk menggantikan materi pembelajaran yang telah disusun untuk tatap muka langsung atau daring. Aplikasi-aplikasi edutainment tersebut memuat konten berkesesuaian dengan Standar Isi pada SN PAUD, sehingga siswa memperoleh lebih banyak manfaat "Belajar Dari Rumah" dan memungkinkan guru mengeksplorasinya untuk pembelajaran.
\end{abstract}

Kata Kunci: pjj tk; sn paud; aplikasi edutainment.

\begin{abstract}
The COVID-19 pandemic triggered a change in national learning, leading to "Learning From Home". Implementation of education becomes distance learning is no exception for Kindergarten (TK) level. Distance learning requires information and communication technology including edutainment application. Edutainment applications can support for learning at TK levels. This paper contains research to obtain edutainment applications that can support TK distance learning refers to National Standard PAUD. This qualitative research uses the observation technique to applications on the Google Play Store with the Android platform. In the next step, performing an analysis of the content of the edutainment applications that had been collected. In the final section, this paper provides a list of applications that support distance learning for TK, not to replace learning materials of both face-to-face or online. The edutainment applications contain the content that accordance with the Content Standards in the PAUD National Standards so the students to get more of the benefits of "Learning From Home" and enable the teachers to explore it for learning.
\end{abstract}

Keywords: kindergarten distance learning; paud national standard; edutainment application.

Copyright (c) 2020 Elviawaty Muisa Zamzami

$\square$ Corresponding author:

Email Address : elvi_zamzami@usu.ac.id (Medan, Sumatera Utara, Indonesia)

Received 5 September 2020, Accepted 12 September 2020, Published 19 September 2020 


\section{PENDAHULUAN}

Pandemi COVID-19 menyebabkan perubahan tatanan kehidupan masyarakat di seluruh dunia, termasuk Indonesia. Salah satu perubahan yang sangat nyata adalah pelaksanaan pendidikan menjadi "Belajar Dari Rumah" (Kemendikbud, 2020). Rumah umumnya dipandang sebagai tempat belajar informal. Pembelajaran informal tidak terstruktur dan peserta didik bertanggungjawab atas pembelajaran mereka. Perkembangan teknologi menjadikan rumah sebagai lingkungan belajar tentang pengetahuan untuk anakanak dengan usia 3 hingga 6 tahun (Vartiainen dan Aksela, 2019). "Belajar Dari Rumah" dimana anak berada di rumah mengikuti pembelajaran dengan guru dari tempat berbeda, dikenal sebagai pembelajaran jarak jauh.

Pendidikan Anak Usia Dini (PAUD) membantu pertumbuhan dan perkembangan anak sehingga anak mempunyai kesiapan yang lebih baik untuk menempuh pendidikan tingkat dasar (Kemendikbud, 2014). Terdapat pengelompokan usia anak untuk PAUD dengan usia anak 4 hingga 6 tahun disebut sebagai usia anak TK. Bersumber data jumlah siswa TK Negeri dan Swasta, untuk tahun 2019/2020 terdapat 3.763.653 siswa di seluruh Indonesia untuk mendapatkan pemenuhan Pendidikan jenjang TK (Pusat Data, 2020). Dengan demikian, terdapat $1,4 \%$ dari penduduk Indonesia sebagai siswa TK. Paper ini membahas PAUD jenjang TK dengan usia anak 5 - 6 tahun.

Pada TK menggunakan pendekatan belajar dan bermain, berinteraksi sesama siswa, guru, sumber belajar, dengan melibatkan orangtua sebagai tangan pertama pendidik anak. Pelaksanaan PAUD merujuk pada SN PAUD. SN PAUD tersusun atas beberapa standar yang merupakan satu kesatuan. Pembahasan pada paper ini merujuk pada Standar Isi pada Pasal 9 dan 10 SN PAUD, mencakup program pengembangan melalui bermain dan pembiasaan terhadap unsur-unsur yang dimuat dalam pasal tersebut. Pembelajaran juga merujuk pada pencapaian perkembangan anak sesuai dengan kelompok usia anak.

Pembelajaran TK dilaksanakan dengan interaksi di dalam ruang belajar ataupun ruang bermain. Namun, pembelajaran TK seyogyanya dapat dilakukan sebagai pembelajaran jarak jauh. Pembelajaran Jarak Jauh (PJJ) memerlukan teknologi informasi dan komunikasi (jaringan internet), teknologi yang dapat memberikan solusi dan kemudahan. Teknologi seluler juga ideal digunakan pada PJJ sebab fleksibel, mudah diakses, tersedia, dan memenuhi berbagai aktivitas interaksi (Makoe dan Shandu, 2018). PJJ dapat menghadirkan pembelajaran tatap muka virtual dan penyampaian materi pembelajaran secara luring ataupun daring. Menghadapi Pandemi COVID-19, pembelajaran pada jenjang TK harus dilakukan sebagai PJJ. PJJ jenjang TK harus tetap dengan pendekatan pada 'Belajar' dan 'Bermain'. Pelaksanaan PJJ TK juga memerlukan pendampingan orang tua, dimana guru dan orang tua sebagai fasilitator pembelajaran anak (Fauziddin, 2016).

Permasalahan pada PJJ adalah pada sebagian besar peserta tidak mempunyai pengalaman praktis dengan model pembelajaran ini. Juga, minimnya tatap muka dengan pendidik atau guru akan berpengaruh terhadap hasil belajar (Fojtík, 2018). Hal ini juga dapat terjadi pada PJJ untuk TK, orangtua memungkinkan tidak memahami hal-hal yang disampaikan oleh guru secara daring. Akibatnya, anak tidak mencapai sasaran pembelajaran. Terkadang, guru juga kesulitan dalam hal penilaian hasil pembelajaran secara obyektif (Ariadhy dkk., 2020). Untuk permasalahan tersebut, siswa TK dapat diberikan pembelajaran tambahan yang mendukung PJJ dengan pendampingan orangtua. Pembelajaran tambahan tersebut menggunakan gawai cerdas yang terkoneksi dengan jaringan internet dan aplikasi edutainment.

Jika menilik dari komponen kata pembentuk istilah "edutainment", maka "edutainment" merupakan gabungan dua buah kata "education" dan "entertainment". Edutainment dipandang sebagai sebuah pendekatan gabungan edukasi dan hiburan. Edukasi dengan hiburan diharapkan lebih memikat, menanamkan kegembiraan, dan membangkitkan emosi (Philipp Niemann dkk., 2020). Terkait pedagogik, edutainment dikonseptualisasikan sebagai sebuah bagian dari experiential learning (Tung, 2015). 
Edutainment bisa menggunakan beberapa media, misalnya radio, televisi, atau film. Menghadapi pandemi COVID-19, pemerintah berusaha tetap memberikan hak belajar setiap anak dengan "Belajar Dari Rumah" menggunakan media televisi. Untuk jenjang PAUD/sederajat disediakan Program Tayangan Belajar Dari Rumah di TVRI selama 30 menit setiap hari dari Senin hingga Jumat (Kemdikbud, 2020). Tayangan tersebut dikemas sebagai edutainment, memuat narasi atau cerita yang menghibur dengan pesan-pesan edukasi (Banerjee dkk., 2019). Namun, di era milenial ini anak usia dini sudah lebih akrab dengan gawai cerdas dibandingkan televisi, sehingga lebih sulit mengajak anak belajar dengan media televisi. Gawai cerdas saat ini relatif murah dan portabel, dilengkapi konektivitas beragam jaringan, berfitur audio dan video digital. Para akademisi internasional juga meyakini bahwa gawai cerdas dapat digunakan untuk meningkatkan pembelajaran dan pengajaran, memungkinkan anak usia dini mengeksplorasi pengetahuan lanjutan (Papadakis dkk., 2018). Gawai (telepon seluler) cerdas harus dilengkapi dengan aplikasi pendukung pembelajaran.

Aplikasi terkadang disingkat sebagai App, merupakan perangkat lunak yang dikembangkan khusus pada platform seluler (Pressman dan Maxim, 2015). Beberapa platform populer pada perangkat telepon cerdas yang tersedia adalah iOS, Android, dan Window Mobile. Aplikasi yang digunakan untuk memberikan edukasi dengan format hiburan dikenal sebagai aplikasi edutainment, tersedia untuk bermacam kelompok usia, dari anak hingga dewasa, guru, juga siswa. Guru pada jenjang TK dituntut selalu terus-menerus berinovasi pada pembelajarannya. Guru dapat bereksplorasi menggunakan aplikasi edutainment sehingga peserta didik terangsang untuk bereksplorasi menemukan pengetahuan (Santoso, 2018).

Peserta didik jenjang TK mempelajari sesuatu didominasi dengan bermain dan permainan (games). Bermain dan permainan menjadi pendorong utama bagi anak, yang dapat memotivasi, memperkuat, mentransfer karakter (Lucas, 2017). Pada kelompok usia TK sudah mampu menggunakan perangkat telepon cerdas sebagai media belajar, dengan menekan tombol, menggeser layar, berinteraksi sesuai aturan (Moldovan dkk., 2019). Hal ini memungkinkan menjadi salah satu alasan para pengembang games membuat khusus untuk kelompok usia dini beragam serious games yang notabene sebagai aplikasi edutainment.

Aplikasi edukasi, termasuk didalamnya edutainment, merupakan aplikasi dalam 4 (empat) kategori teratas yang paling banyak diakses pada platform Android dan mendominasi lebih dari 80\% aplikasi di penyedia aplikasi iTunes dan Google Play (Zigh dkk., 2020). Juga, banyak paper ilmiah dan artikel membahas aplikasi edutainment yang dapat digunakan sebagai pendukung pembelajaran. Paper ini membahas aplikasi edutainment yang dapat digunakan anak TK sebagai pendukung pembelajaran TK dengan konten sesuai Standar Isi pada SN PAUD. Standar Isi dimuat pada Bab IV Peraturan Mendikbud RI No.137 Thn 2014 dengan rincian pada Lampiran 1 SN PAUD (Kemendikbud, 2014). Paper ini tidak membahas aplikasi edutainment dari aspek antarmuka pengguna atau lainnya yang terkait dengan pengembangan aplikasinya.

Aplikasi edutainment berkonten sesuai dengan Standar Isi Standar Nasional PAUD dapat juga sebagai pendukung pembelajaran pada sekolah maupun daerah yang kekurangan dalam hal kemampuan guru. Masih terdapat daerah dengan guru yang relatif masih terbatas hanya pada kegiatan mewarnai, menggunting, dan menempel. Kegiatan tersebut sering dilakukan bergantian (Sum dan Taran, 2020). Seharusnya, pembelajaran memuat kegiatan kreatif, unik, juga inovatif (Maulida dan Nadiyah, 2019). Aplikasi edutainment tidak hanya untuk anak sebagai siswa, tetapi juga dapat digunakan untuk peningkatan kemampuan guru, serta sebagai upaya anak lebih dekat dengan orangtua atau keluarganya. Dari paparan di atas, maka penelitian ini mempunyai rumusan permasalahan yaitu bagaimana memperoleh aplikasi edutainment yang mendukung PJJ jenjang TK mengacu Standar Isi pada SN PAUD. 


\section{METODOLOGI}

Paper ini memuat penelitian penulis dengan metode kualitatif. Tahapan-tahapan penelitian dilaksanakan seperti pada Gambar 1.

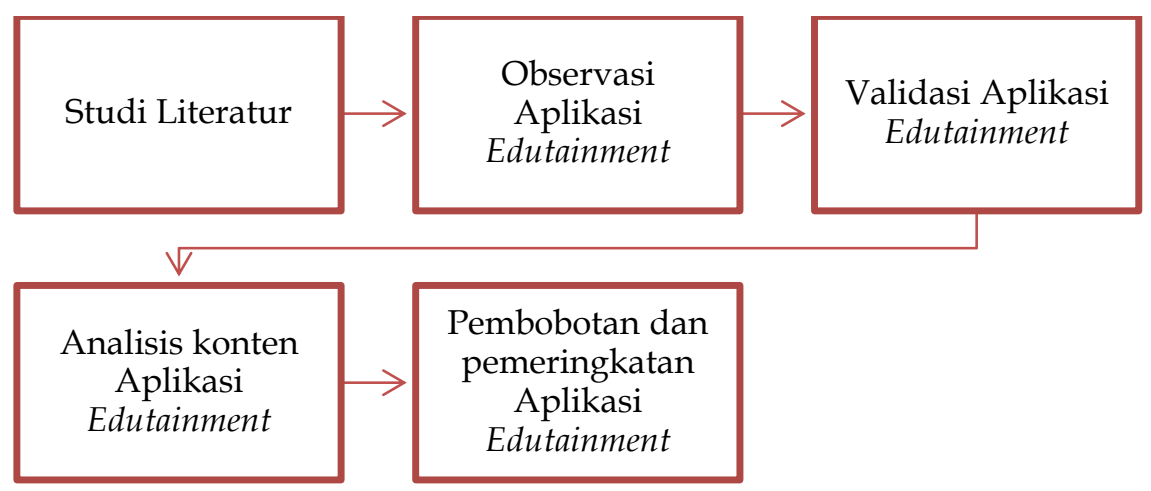

Gambar 1. Tahapan penelitian

Penelitian diawali dengan studi literatur tentang pembelajaran jarak jauh, PAUD dan TK, SN PAUD, serta aplikasi edutainment. Sumber literatur bersumber dari peraturan pemerintah, laman web, penyedia aplikasi, buku teks, serta paper pada jurnal dan prosiding nasional/internasional.

Untuk mengumpulkan data penelitian dilakukan dengan metode observasi terhadap aplikasi-aplikasi edutainment yang menggunakan platform Android. Dari statistik, diketahui Android saat ini masih menguasai pasar Indonesia mencapai lebih dari 90 \% (GlobalStats, 2020). Aplikasi-aplikasi tersebut dapat diakses dari penyedia aplikasi seluler (mobile) yaitu Google Play Store (HealthTap, 2016). Dikumpulkan masing-masing 50 aplikasi yang termasuk kedalam pemeringkatan teratas aplikasi yang tersedia pada Google Play Store dengan beberapa kriteria, yaitu "Family" tidak berbayar (free), kelompok usia "Ages 5 \& Under" dan "Ages 6-8", dan kategori aplikasi "Education". Pada tahap ini penulis juga mengumpulkan aplikasi dari AppBrain yang memuat beragam hal tentang aplikasi Android, antara lain peringkat aplikasi (AppBrain, 2020). Pengumpulan aplikasi dilaksanakan pada bulan Juni 2020.

Tahap selanjutnya adalah melakukan verifikasi terhadap aplikasi yang telah dikumpulkan. Verifikasi untuk memastikan aplikasi yang dikumpulkan adalah aplikasi edutainment dan memeriksa "star ratings" yang diberikan oleh pengguna aplikasi. Setelah aplikasi edutainment diverifikasi, maka aplikasi akan dianalisis kontennya. Konten dianalisis kesesuaiannya terhadap unsur-unsur pada Standar Isi pada SN PAUD untuk usia anak TK (5 hingga 6 tahun). Untuk kesesuaian yang didapat, dilakukan pembobotan terhadap aplikasi edutainment dengan nilai bobot maksimal 6 .

\section{HASIL DAN PEMBAHASAN}

Mengacu tahapan-tahapan penelitian yang telah disampaikan pada bagian sebelumnya, maka pelaksanaan penelitian ini mempunyai gambaran umum seperti pada Gambar 2.

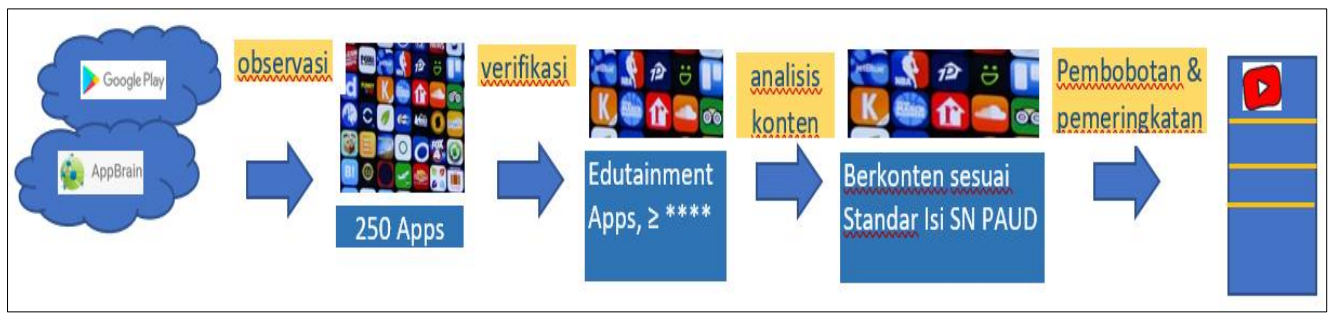

Gambar 2. Gambaran umum pelaksanaan penelitian 
Penelitian ini menggunakan aplikasi-aplikasi yang disediakan oleh Google Play Store dengan beberapa kategori. Kategori-kategori yang dipilih adalah "Family" yang tidak berbayar (free), "Ages 5 \& Under", "Ages 6-8", "Education". Pemilihan kategori tersebut karena pada "Family" memungkinkan aplikasi yang dibutuhkan pada penelitian ini dijalankan bersama keluarga, kategori "Ages 5 \& Under" dan kategori "Ages 6-8" disebabkan target usia anak TK adalah 5-6 tahun, dan kategori "Education" karena memungkinkan aplikasi edutainment dikategorikan ke dalam aplikasi edukasi. Dari setiap kategori dikumpulkan 50 aplikasi, sesuai urutan tampilan pada setiap kategori. Dengan demikian, diperoleh 200 aplikasi dari Google Play. Penelitian ini juga mengumpulkan 50 aplikasi edukasi hasil pemeringkatan AppBrain. Dengan demikian, penelitian ini mengunakan data berupa 250 aplikasi yang diperoleh pada bulan Juni 2020.

Selanjutnya, melakukan verifikasi terhadap aplikasi untuk memastikan mempunyai nilai edukasi dan nilai bermain sesuai dengan pendidikan anak usia TK. Verifikasi juga dilakukan terhadap peringkat bintang (star ratings) yang dimiliki oleh aplikasi. Peringkat bintang aplikasi seluler menunjukkan peringkat aplikasi terhadap unduhan, umpan balik dan komentar pengguna, update, serta pembelian aplikasi oleh pengguna aplikasi. Nilai bintang menjadi penting untuk pengguna baru yang mempercayai pemeringkatan bintang untuk mengunduh aplikasi (Monett dan Stolte, 2016). Pada paper ini, aplikasi edutainment yang dibutuhkan minimal bernilai 4 bintang. Namun, masih memungkinkan nilai bintang tidak mewakili informasi dari pengguna. Pengguna harus bijak memilih aplikasi yang sesuai dengan kebutuhan (Rodrigues dkk., 2019). Dari tahapan ini diambil 50 aplikasi edutainment dari Google Play dan 10 aplikasi edutainment dari AppBrain.

Tahapan berikutnya menganalisis terhadap konten-konten aplikasi untuk menentukan apakah konten tersebut sesuai dengan unsur-unsur yang dimuat dalam Standar Isi pada SN PAUD untuk anak usia TK. Tahapan verifikasi dan analisis dilakukan dengan menjalankan (running) aplikasi.

Aplikasi edutainment dapat mendukung lingkup perkembangan anak terhadap nilainilai agama dan moral yang berlaku di masyarakat, misalnya aplikasi mempunyai konten edukasi tentang tata cara pelaksanaan ibadah buat anak sehingga menjadi pembiasaan anak sesuai dengan kelompok usia TK (5 hingga 6 tahun). Contoh lain, aplikasi yang memuat konten cara menjaga kebersihan diri serta lingkungan. Konten-konten tersebut sesuai dengan Pasal 10 ayat (2) dari Standar Isi.

Untuk aplikasi edutainment yang mendukung Pasal 10 ayat (3) Standar Isi, akan memberikan konten mengajak anak melatih motorik kasar dengan mengikuti tarian, olah raga, dengan menggerakkan anggota badan ke kanan dan ke kiri. Aplikasi edutainment juga dapat melatih motorik halus dengan memberikan konten belajar menggambar. Konten lainnya misalnya memuat cara mencuci tangan yang benar sebagai upaya menjaga kesehatan dan dapat membantu pemahaman anak terhadap pandemi Covid-19.

Standar Isi berikutnya adalah dalam hal kognitif, dimuat pada Pasal 10 ayat (4) Standar Isi. Merujuk standar tersebut, aplikasi memberikan konten yang dapat membantu belajar serta menemukan penyelesaian masalah sederhana dengan ide kreatf. Konten yang melatih berfikir logis, misalkan mengelompokkan benda menurut warna dan mengurutkan benda menurut ukurannya. Untuk usia anak TK, aplikasi juga memberikan konten dalam hal perkembangan kemampuan berfikir simbolik dengan simbol huruf dan angka.

Berikutnya, untuk aplikasi edutainment yang mendukung Pasal 10 ayat (5) Standar Isi berarti aplikasi mempunyai konten terkait perkembangan kemampuan anak terhadap bahasa. Kelompok usia anak TK memahami bahasa yang mulai kompleks. Aplikasi dapat memberikan perintah-perintah yang harus dilakukan anak, juga menambah perbendaharaan kata anak. Aplikasi juga dapat menyediakan konten terkait keaksaraan, sehingga anak mampu menulis dan membaca susunan simbol huruf membentuk suku kata. 
Untuk mendukung pembelajaran sesuai dengan Pasal 10 ayat (6) Standar Isi, aplikasi edutainment mempunyai konten terkait perkembangan sosial-emosional. Konten dapat berupa gambaran situasi sekitar, atau menyampaikan cara menjaga diri sendiri di berbagai situasi. Aplikasi juga dapat memuat konten untuk perkembangan perilaku prososial, memberikan respon yang wajar terhadap sesuatu, dan membuat anak mempunyai tata krama yang berlaku di masyarakat setempat.

Aplikasi edutainment yang mempunyai konten mengenalkan beragam nama dan suara alat musik, mengajak bernyanyi dan menikmati lagu dapat digunakan sebagai pendukung pembelajaran terkait perkembangan seni bagi anak. Konten mendukung seni lainnya adalah memberikan drama sederhana dengan berbagai peran, yang memungkinkan anak tertarik pada peran tertentu. Konten lainnya memberikan cara melukis sederhana dengan berbagai alat melukis pada beberapa media. Aplikasi edutainment dengan konten tersebut mendukung pembelajaran sesuai Standar Isi untuk Pasal 10 ayat (7). Analisis konten menghasilkan daftar aplikasi edutainment berkonten sesuai dengan Standar Isi SN PAUD. Daftar aplikasi edutainment tersebut dimuat pada Tabel 1 dengan penyajian menurut komponen lingkup perkembangan anak.

Tabel 1. Aplikasi Edutainment Pendukung Pembelajaran PAUD/TK.

\begin{tabular}{|c|c|}
\hline $\begin{array}{c}\text { Lingkup } \\
\text { Perkembangan }\end{array}$ & Aplikasi Edutainment Pendukung \\
\hline $\begin{array}{l}\text { I. } \\
\text { Nilai Agama } \\
\text { dan Moral }\end{array}$ & $\begin{array}{l}\text { YouTube Kids, Bubbu - My Virtual , Baby Panda'sSupermarket, Baby Panda'sIce } \\
\text { Cream Shop , Baby Panda'sCooking Restaurant, BabyPanda: Dental Care , Little } \\
\text { PandaPoliceman , BabyPanda: Care for animals , Baby Panda'sSchool Bus - } \\
\text { Let'sDrive! , Baby Panda'sFire Safety, Doctor Kids, Baby Panda'sTown: Life, , } \\
\text { BabyPanda Care , Baby Panda'sLife: Cleanup , BabyPanda's Summer: Café , } \\
\text { Aplikasi Belajar Tk Paud Materi Lengkap , Bible App for Kids: Audio \& } \\
\text { Interactive Stories, Belajar Al-Quran + Suara , Paket Belajar Lengkap TK \& PAUD } \\
\text {, Belajar Shalat + Audio - Marbel }\end{array}$ \\
\hline $\begin{array}{l}\text { II. } \\
\text { Fisik-motorik }\end{array}$ & 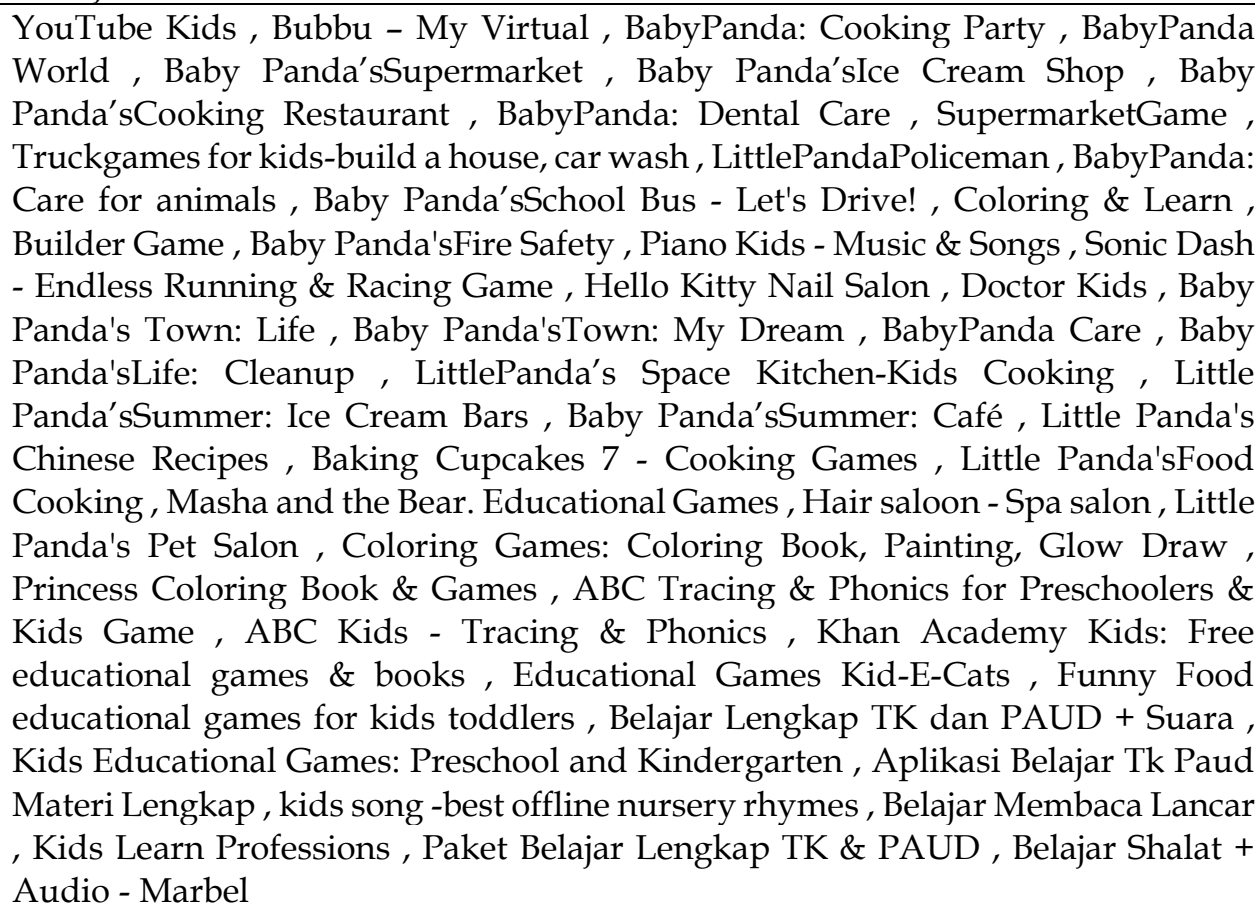 \\
\hline $\begin{array}{l}\text { III. } \\
\text { Kognitif }\end{array}$ & $\begin{array}{l}\text { YouTube Kids , Bubbu - My Virtual , BabyPanda: Cooking Party , BabyPanda } \\
\text { World , Baby Panda'sSupermarket , BabyPanda's Ice Cream Shop , BabyPanda's } \\
\text { Cooking Restaurant, BabyPanda: Dental Care, SupermarketGame , LittlePanda's } \\
\text { Restaurant, Truckgames for kids- build a house, car wash, Little PandaPoliceman } \\
\text {, Baby Panda: Care for animals , BabyPanda's School Bus-Let's Drive! , Coloring }\end{array}$ \\
\hline
\end{tabular}




\begin{tabular}{|c|c|}
\hline $\begin{array}{c}\text { Lingkup } \\
\text { Perkembangan }\end{array}$ & Aplikasi Edutainment Pendukung \\
\hline & 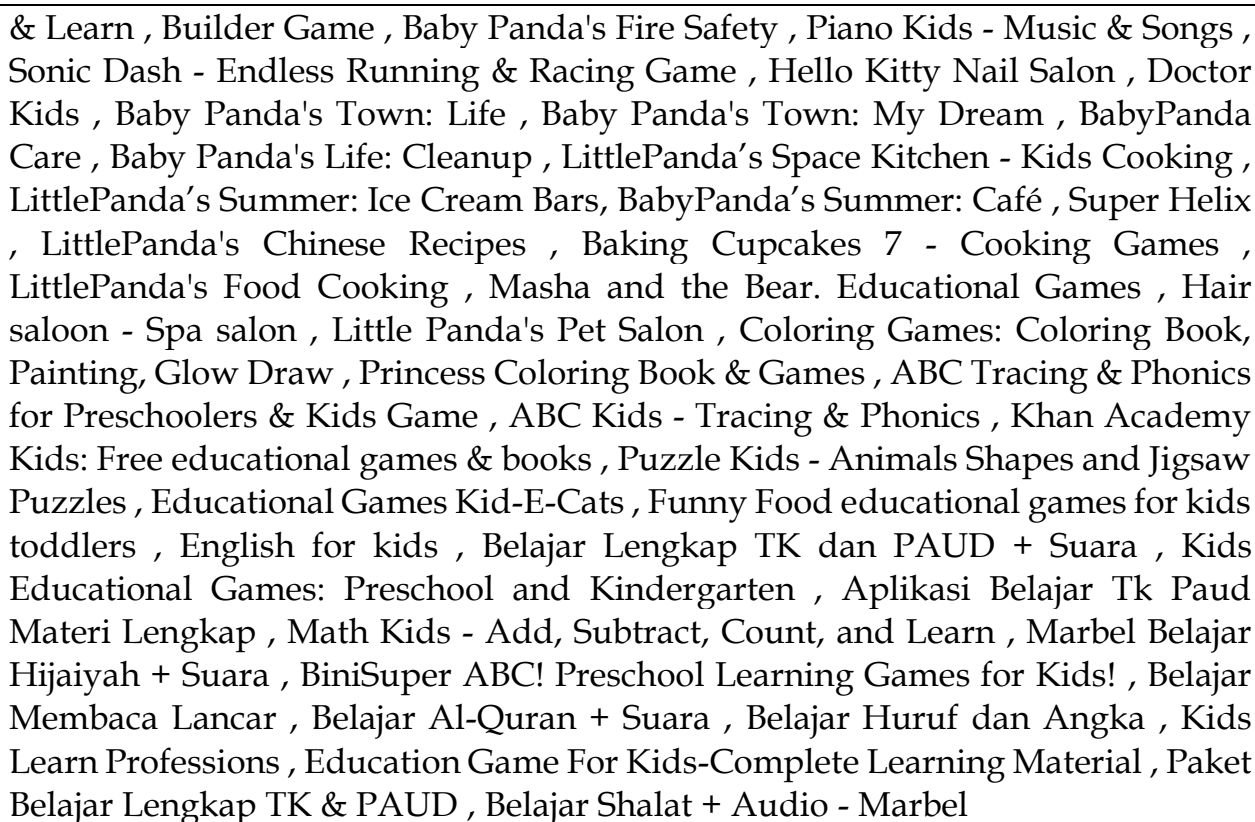 \\
\hline $\begin{array}{l}\text { IV. } \\
\text { Bahasa }\end{array}$ & 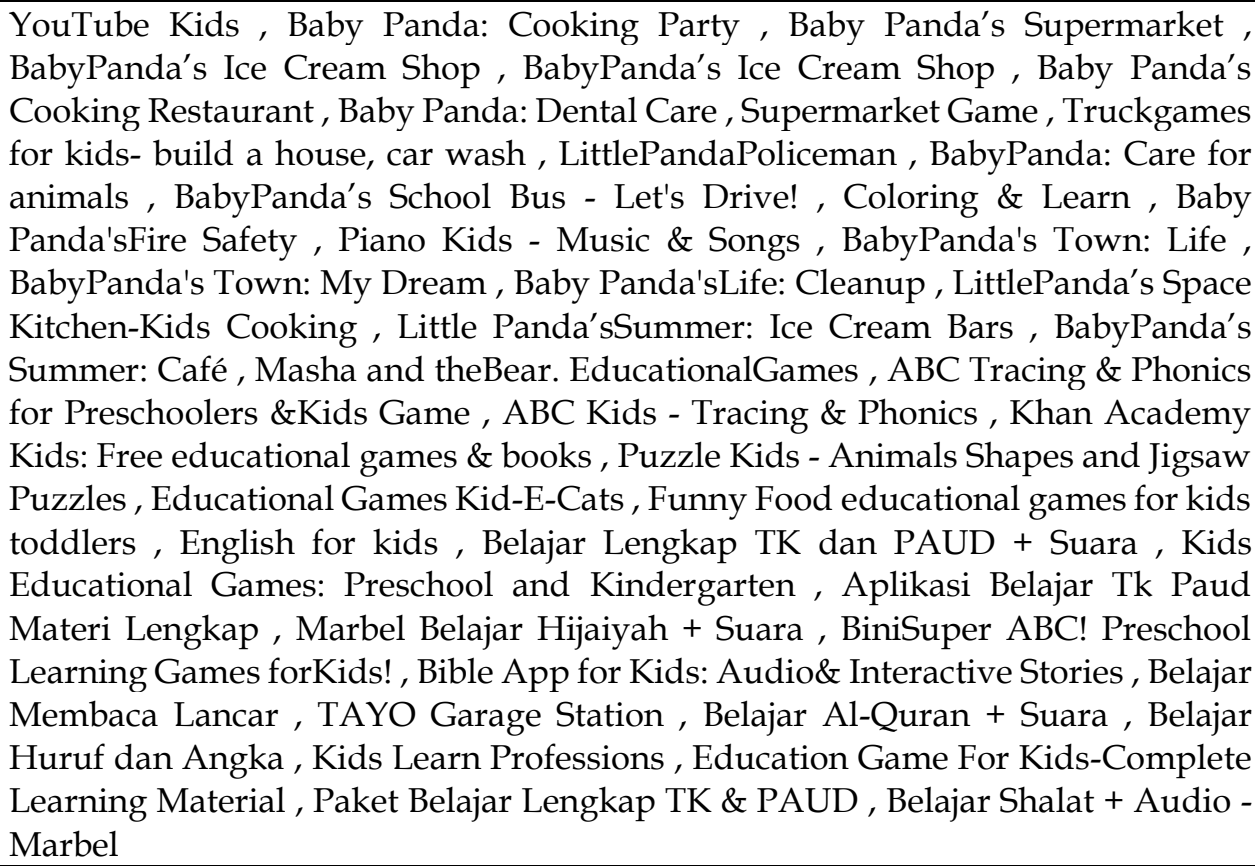 \\
\hline $\begin{array}{l}\text { V. } \\
\text { Sosial- } \\
\text { emosional }\end{array}$ & $\begin{array}{l}\text { YouTube Kids, Bubbu - My Virtual, BabyPanda: Cooking Party , Baby Panda } \\
\text { World, Baby Panda'sSupermarket, BabyPanda's Ice Cream Shop , BabyPanda's } \\
\text { Cooking Restaurant, BabyPanda: Dental Care , LittlePanda's Restaurant , } \\
\text { Truckgames for kids- build a house, car wash , LittlePandaPoliceman, } \\
\text { BabyPanda: Care for animals , BabyPanda's School Bus - Let's Drive! , } \\
\text { BabyPanda's Fire Safety , Doctor Kids, Baby Panda'sTown: Life , BabyPanda's } \\
\text { Town: My Dream, BabyPanda Care , BabyPanda's Life: Cleanup , LittlePanda's } \\
\text { Space Kitchen-Kids Cooking , LittlePanda'sSummer: Ice Cream Bars , } \\
\text { BabyPanda'sSummer: Café, LittlePanda's Chinese Recipes, Little Panda's Food } \\
\text { Cooking, Masha and theBear. EducationalGames, Hair saloon - Spa salon , } \\
\text { LittlePanda's Pet Salon, Educational Games Kid-E-Cats, Funny Food educational } \\
\text { games for kids toddlers , Belajar Lengkap TK dan PAUD + Suara , Kids } \\
\text { Educational Games: Preschool and Kindergarten , Aplikasi Belajar Tk Paud } \\
\text { Materi Lengkap, Bible App for Kids: Audio \&Interactive Stories, TAYO Garage } \\
\text { Station, Kids Learn Professions , Education Game For Kids- Complete Learning } \\
\text { Material, Paket Belajar Lengkap TK \& PAUD , Belajar Shalat + Audio - Marbel }\end{array}$ \\
\hline
\end{tabular}




\begin{tabular}{l|l}
\hline $\begin{array}{c}\text { Lingkup } \\
\text { Perkembangan }\end{array}$ & \multicolumn{1}{c}{ Aplikasi Edutainment Pendukung } \\
\hline & $\begin{array}{l}\text { YouTube Kids , Bubbu - My Virtual , BabyPanda's School Bus - Let'sDrive! , } \\
\text { Coloring \& Learn , PianoKids - Music \& Songs , Hello Kitty Nail Salon , Baby } \\
\text { Panda Care , Baking Cupcakes 7 - Cooking Games , Masha and the Bear. }\end{array}$ \\
& $\begin{array}{l}\text { Educational Games , Hair saloon - Spa salon , Little Panda'sPet Salon , Coloring } \\
\text { VI. }\end{array}$ \\
Geni & $\begin{array}{l}\text { Educational Games Kid-E-Cats, Funny Food educational games for kids toddlers } \\
\text {, Belajar Lengkap TK dan PAUD + Suara , Aplikasi Belajar Tk Paud Materi } \\
\text { Lengkap , kids song - best offline nursery rhymes , Belajar Al-Quran + Suara , } \\
\text { Education Game For Kids-Complete Learning Material , Paket Belajar Lengkap } \\
\end{array}$ \\
\hline
\end{tabular}

Bagian akhir pada tahapan pelitian ini adalah pembobotan dan pemeringkatan aplikasi edutainment. Setiap kelompok unsur Standar Isi yang dimuat pada konten aplikasi akan diberi bobot 1 (satu), sehingga bobot maksimal aplikasi adalah 6 (enam). Bobot aplikasi 6 berarti konten aplikasi edutainment tersebut memuat semua kelompok unsur Standar Isi (Pasal 10 Ayat 2 - 7) untuk anak usia TK. Bobot ini digunakan untuk pemeringkatan aplikasi edutainment tersebut. Aplikasi edutainment dengan konten lengkap mendukung semua kelompok unsur pembelajaran sesuai Standar Isi untuk anak usia 5-6 tahun, dimuat pada Tabel 2.

Tabel 2. Aplikasi Edutainment Berkonten Semua Kelompok Unsur Standar Isi SN PAUD

\begin{tabular}{|c|c|c|}
\hline \multicolumn{2}{|l|}{ Nama Aplikasi } & URL Penyedia \\
\hline YouTube Kids & & $\begin{array}{l}\text { https://play.google.com/store/apps/details?id=com.google } \\
\text { android.apps.youtube.kids }\end{array}$ \\
\hline $\begin{array}{l}\text { Aplikasi Belajar Tk Paud } \\
\text { Materi Lengkap }\end{array}$ & कीm & $\begin{array}{l}\text { https://play.google.com/store/apps/details?id=com.hybrid } \\
\text { paket_belajar_1 }\end{array}$ \\
\hline $\begin{array}{l}\text { Paket Belajar Lengkap TK \& } \\
\text { PAUD }\end{array}$ & $2 \sqrt{2.78}$ & $\begin{array}{l}\text { https://play.google.com/store/apps/details?id=com.evamu } \\
\text { chtar.abc.remix }\end{array}$ \\
\hline
\end{tabular}

Dari hasil penelitian ini, aplikasi edutainment dengan konten mendukung perkembangan kognitif mendominasi dengan 56 aplikasi. Aplikasi edutainment mendukung perkembangan fisik-motorik diperoleh 48 aplikasi. Selanjutnya, diperoleh 41 aplikasi edutainment untuk mendukung perkembangan bahasa anak. Untuk mendukung perkembangan sosial dan emosional anak diperoleh 39 aplikasi edutainment. Aplikasi edutainment untuk mendukung anak dalam hal seni diperoleh 21 aplikasi. Sedangkan aplikasi untuk mendukung perkembangan anak dalam hal nilai agama dan moral diperoleh 20 aplikasi edutainment.

Aplikasi-aplikasi edutainment yang diperoleh dari penelitian ini direpresentasikan menurut kelompok unsur pembelajaran pada Standar Isi SN PAUD (Tabel 1). Dengan representasi tersebut, orang tua dan guru dapat memilih aplikasi untuk mendukung pembelajaran sesuai dengan kebutuhan pembelajaran anak dan juga minat pada anak. Sebuah aplikasi edutainment memungkinkan memiliki konten yang mendukung beberapa atau semua kelompok unsur pembelajaran merujuk Standar Isi pada SN PAUD.

Dari penelitian ini diperoleh aplikasi YouTube Kids, Aplikasi Belajar Tk Paud Materi Lengkap, dan Paket Belajar Lengkap TK \& PAUD mendukung semua kelompok unsur pembelajaran sesuai Standar Isi untuk anak usia 5-6 tahun (Tabel 2). YouTube Kids sebagai penyedia konten video anak dengan topik Seni \& Kerajinan, Mainan \& Bermain, Pelajaran \& Hobi, serta Acara \& Kartun (YouTube Kids, 2020). Dengan aplikasi ini orang tua dapat mengawasi pemilihan konten yang dapat ditonton oleh anak dan waktu penggunaannya, sehingga anak memperoleh kesesuaian konten dan waktunya (Burroughs, 2017). 
Dari penelitian ini diperoleh bahwa aplikasi edutainment yang dapat mendukung anak mulai membiasakan beribadah sesuai agama yang dianut hampir seluruhnya untuk anak beragama Islam, tidak diperoleh untuk agama Hindu dan Budha. Juga, aplikasi-aplikasi edutainment yang dimuat pada Tabel 1 pada umumnya menggunakan bahasa Inggris. Hal ini juga menjadi suatu tantangan dimana pada umumnya anak TK di Indonesia menggunakan bahasa ibu, Bahasa Indonesia. Namun, terdapat Aplikasi Belajar Tk Paud Materi Lengkap dan aplikasi Paket Belajar Lengkap TK \& PAUD yang mendukung semua komponen unsur Standar Isi SN PAUD dengan bahasa Indonesia dan mempunyai kemiripan konten dengan materi pembelajaran langsung (tatap muka).

Penggunaan aplikasi-aplikasi edutainment yang dimuat pada paper ini tetap harus didampingi oleh orang dewasa, idealnya orang tua. Meskipun konten yang dimiliki aplikasi sudah sesuai dengan yang dimaksudkan, anak masih bisa memungkinkan 'terseret' link yang tidak seharusnya, misalkan karena adanya iklan pada aplikasi tidak berbayar (free). Juga, orang tua harus membatasi waktu penggunaan gawai (telepon cerdas), agar anak memanfaatkannya sebagai pembelajaran yang sehat dan aman sehingga mendukung PJJ jenjang TK.

Penyelenggaraan “Belajar Dari Rumah" oleh adanya Pandemi Covid-19 tidak berarti setelah teratasinya pandemi kembali ke pembelajaran tatap muka di kelas saja, tetapi dapat memadukannya dengan pembelajaran daring (blended learning), sebagai salah satu model pembelajaran untuk pendidikan digital 4.0 (Jaya Saragih et al., 2020). Kondisi pandemi dijadikan sebagai pemicu untuk menggiatkan semua pelaksanaan pembelajaran menggunakan teknologi informasi dan komunikasi. termasuk didalamnya aplikasi edutainment. Hal ini dimulai dari jenjang pendidikan PAUD, khususnya jenjang TK untuk mempersiapkan siswa (anak) yang paham teknologi informasi dasar secara aman dan sehat.

\section{SIMPULAN}

Paper ini memuat daftar aplikasi edutainment dengan platform Android yang mendukung PJJ TK. Aplikasi-aplikasi edutainment tersebut bukan menggantikan materi pembelajaran yang telah direncanakan untuk pembelajaran tatap muka langsung ataupun daring. Penggunan aplikasi edutainment tersebut dapat mendukung minat belajar, penguasaan pengetahuan, pembentukan karakter, dan lainnya untuk pertumbuhan dan perkembangan anak. Juga, guru dapat memanfaatkannya untuk mengekplorasi materi pembelajaran. Orangtua siswa dapat memilih dan memfokuskan penggunaan aplikasi-aplikasi edutainment sesuai dengan kebutuhan anak. Orangtua tetap dibutuhkan mendampingi anak dalam penggunaan aplikasi edutainment, disebabkan usia anak yang masih dini. Penelitian mendatang, memungkinkan pengembangan sistem rekomendasi mengacu pada SN PAUD terintegrasi dengan penyedia aplikasi.

\section{UCAPAN TERIMA KASIH}

Penulis mengucapkan terima kasih kepada seluruh guru TK Dharma Wanita Persatuan Universitas Sumatera Utara yang memberikan dukungan sehingga penelitian yang dilaksanakan oleh penulis selesai dilaksanakan, juga siswa yang terlibat pada running aplikasi edutainment tersebut.

\section{DAFTAR PUSTAKA}

AppBrain. (2020). Google Play Ranking: Top Free Education Apps in Indonesia I AppBrain. https://www.appbrain.com/stats/google-play-rankings/top_free/education/id

Ariadhy, S. Y., Nurohman, S., Arkum, D., \& Handini, W. (2020). Pelatihan pembelajaran jarak jauh di era pandemi covid-19. JURNAL ANOA, 1(3), 220-226. http://ojs.uho.ac.id/index.php/anoa/article/view/13640

Banerjee, A., La Ferrara, E., \& Orozco Olvera, V. (2019). The Entertaining Way to Behavioral 
DOI: $10.31004 /$ obsesi.v5i2.750

Change: Fighting HIV with MTV. National Bureau of Economic Research. https:/ / doi.org/10.3386/w26096

Burroughs, B. (2017). Youtube kids: The app economy and mobile parenting. Social Media and Society, 3(2). https:/ / doi.org/10.1177/2056305117707189

Fauziddin, M. (2016). Pembelajaran Agama Islam Melalui Bermain Pada Anak Usia Dini. Jurnal Obsesi: Jurnal Pendidikan Anak Usia Dini, 2(2), 107-116. https:// doi.org/10.31004/obsesi.v2i2.37

Fojtík, R. (2018). Problems of Distance Education. International Journal of Information and Communication Technologies in Education, 7(1), 14-23. https://doi.org/10.2478/ijicte2018-0002

GlobalStats. (2020). Mobile Operating System Market Share Indonesia | StatCounter Global Stats. Www.Gs.Statcounter.Com.

HealthTap. (2016). Android Apps on Google Play. Google Play, 17-19. https:// play.google.com/store/apps/details?id=com.healthtap.userhtexpress\&hl=en GB

Jaya Saragih, M., Mas Rizky Yohannes Cristanto, R., Effendi, Y., \& Zamzami, E. M. (2020). Application of Blended Learning Supporting Digital Education 4.0. Journal of Physics: Conference Series, 1566(1), 12044. https:/ / doi.org/10.1088/1742-6596/1566/1/012044

Kemdikbud. (2020). Jadwal Acara Program Belajar dari Rumah di TVRI Minggu Kedua 19 April 2020. https://www.kemdikbud.go.id/main/blog/2020/04/jadwal-acara-programbelajar-dari-rumah-di-tvri-minggu-kedua

Kemendikbud. (2014). Peraturan Menteri Pendidikan dan Kebudayaan Republik Indonesia Nomor 137 Tahun 2014.

Kemendikbud. (2020). Surat Edaran Nomor 4 Tahun 2020 Tentang Pelaksanaan Kebijakan Pendidikan Dalam Masa Darurat Penyebaran CoronaVirus Disease (COVID-19).

Lucas, F. M. M. (2017). The Game as an Early Childhood Learning Resource for Intercultural Education. Procedia - Social and Behavioral Sciences, 237, 908-913. https:// doi.org/10.1016/j.sbspro.2017.02.127

Makoe, M., \& Shandu, T. (2018). Developing a mobile app for learning english vocabulary in an open distance learning context. International Review of Research in Open and Distance Learning, 19(4), 208-221. https:/ / doi.org/10.19173/irrodl.v19i4.3746

Maulida, M. L., \& Nadiyah, N. (2019). Implementasi model pembelajaran edutainment dan tematik terhadap perkembangan kreativitas anak di kelompok bermain aisyiah mutiara ummi kalasan yogyakarta. JEA (Jurnal Edukasi AUD), 5(2). https:// doi.org/10.18592/jea.v5i2.3202

Moldovan, A., Guran, A.-M., \& Cojocar, G.-S. (2019). Developing edutainment applications for Romanian preschoolers. In International Journal of User-System Interaction (Vol. 12, Issue 2019).

Monett, D., \& Stolte, H. (2016). Predicting star ratings based on annotated reviews of mobile apps. Proceedings of the 2016 Federated Conference on Computer Science and Information Systems, FedCSIS 2016, 421-428. https:/ / doi.org/10.15439/2016F141

Niemann, P., Bittner, L., Schrögel, P., \& Hauser, C. (2020). Science Slams as Edutainment: A Reception Study. Media and Communication, 8(1), 177-190. https:/ / doi.org/10.17645/mac.v8i1.2459

Papadakis, S., Kalogiannakis, M., \& Zaranis, N. (2018). Educational apps from the Android Google Play for Greek preschoolers: A systematic review. Computers and Education, 116, 139-160. https://doi.org/10.1016/j.compedu.2017.09.007

Pressman, R. S., \& Maxim, B. R. (2015). Software Engineering : A Practitioner's Approach, Eighth Edition. McGraw-Hill Education.

Pusat Data. (2020). Statistik PAUD Pendidikan Anak Usia Dini 2019/2020.

Rodrigues, P., Silva, I., Barbosa, G., Coutinho, F., \& Mourão, F. (2019). Beyond the stars: Towards a novel sentiment rating to evaluate applications in web stores of mobile apps. 
DOI: 10.31004 /obsesi.v5i2.750

26th International World Wide Web Conference 2017, WWW 2017 Companion, 109-117. https://doi.org/10.1145/3041021.3054139

Santoso. (2018). Penerapan Konsep Edutainment dalam Pembelajaran di Pendidikan Anak Usia Dini (PAUD). Inopendas Jurnal Ilmiah Kependidikan, 1(1), 61-68. https://doi.org/https://doi.org/10.24176/jino.v1i1.2376

Sum, T. A., \& Taran, E. G. M. (2020). Kompetensi Pedagogik Guru PAUD dalam Perencanaan dan Pelaksanaan Pembelajaran. Jurnal Obsesi : Jurnal Pendidikan Anak Usia Dini, 4(2), 543. https:// doi.org/10.31004/obsesi.v4i2.287

Tung, W. H. (2015). Liberal Studies Students' Conceptions of "Edutainment." The University of Hong Kong.

Vartiainen, J., \& Aksela, M. (2019). Science at home: Parents' need for support to implement video-based online science club with young children. LUMAT, 7(1), 59-78. https://doi.org/10.31129/LUMAT.7.1.349

YouTube Kids. (2020). YouTube Kids - Aplikasi Khusus Anak-Anak. https://www.youtube.com/intl/ALL_id/kids/

Zigh, E., Elhoucine, A., Mallek, A., Kadiri, M., Belkacem, K., \& Ensari, T. (2020). Smartphone learning for Kids edutainment. ACM International Conference Proceeding Series, 1-5. https://doi.org/10.1145/3386723.3387862 